\title{
Design Driven Innovation Practices in Design-preneur led Creative Industry
}

\author{
Philips Kembaren', Togar M. Simatupang², Dwi Larso³, Dudy Wiyancoko4
}

\begin{abstract}
Design driven innovation has emerged to be an alternative way to generate sustainable competitive products or services. Previous research has recently revealed succesful practices of design driven innovation in various industries. However, little has been known about the creative companies that practice design driven innovation, especially in developing countries. This research investigates the existence and practices of design-driven innovation in the Indonesian creative industry. Based on interviews with the design-preneurs of the creative industry, one of the results of this study reveals how the Indonesian creative industry creates new meanings that are embedded into new products. Based on the identification, a framework to create new meanings is resulted which consists of a set of key processes, such as sensing, sensemaking, specifying, setting up, and storytelling. The practical contribution of this research is that this identified framework can be adopted by any creative companies interested in improving their innovation capability.
\end{abstract}

Keywords: creative industry; design driven innovation; design-preneur; design thinking; innovation.

\footnotetext{
1,2,3 School of Business and Management, Bandung Institute of Technology, Bandung 40I 32, Indonesia

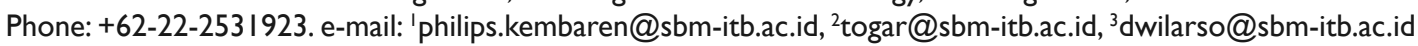

${ }^{4}$ Faculty of Arts and Design, Bandung Institute of Technology, Bandung 40I32, Indonesia. e-mail: dudywiyancoko@gmail.com
}

ISSN: 07 I8-2724. (http://www.jotmi.org)

Journal of Technology Management \& Innovation (c) Universidad Alberto Hurtado, Facultad de Economía y Negocios. 


\section{Introduction}

In recent years, new nature of innovation is emerging, as stated in the Preface of New Nature of Innovation Report to OECD (Prahalad et al., 2009),"co-creation, user involvement, environmental and societal challenges increasingly drive innovation today. Collaborative, global networking and new public private partnerships are becoming crucial elements in companies' innovation process". Firms now innovate in various ways, not just through science and technology. From this emerging trend, there come different new variations of the approach, i.e. open innovation, user-centered innovation, collaborative innovation network, design-driven innovation, and many others. Among them, design-driven approach has its own interesting point. What makes design-driven innovation interestingis because people are increasingly turning to design and creativity as a new paradigm to understand the needs and desires of changing cultures and create new options that never existed before.

The latest ongoing transition role of design relates to intangible issues: innovation and competitiveness amongst global competition (Valtonen, 2010). A national research on the design impact to the UK industry done by Design Council UK (DC, 2008) comes out with promising results: the design industry is a source of innovation, investing in a design allows businesses to compete in numerous ways to avoid a price war, a good design is a source of competitive advantage and businesses are now increasingly using a design to compete.

This research is focused on exploring how design driven innovation isimplemented in indonesian creative industry, and the research problem is formulated as follows: how does creative industry in Indonesia carry out a design driven approach in its innovation process? Exploratory case study is used as the method of this research by which the interviews with the selected design-preneurs of creative industry were conducted to investigate how they introduce a new meaning into the marketplace.

This research paper is structured as follows. It starts with a description of design-driven innovation (DDI) that is adopted by Indonesian creative industry along with the short explanation about Indonesian case. It is then followed by the section that presents the design of this research explaining about the research questions, selection of research method and DDI Process Theoretical Framework.After this section, it is followed by the section that presents the execution of this research, which includes such steps as case selection, data collection and data analysis, the result of which is formulated in DDI Process Conceptual Framework. The result isthen further elaborated for both its theoretical and its practical application in the Discussion and Implications section. This paper concludes with a conclusion section.

\section{Design-driven Innovation}

DDI concept start to emerge during 1980s when Jim Utterback and Bengt-Arne Vedin became part of a team of Swedish and American researchers conducting study to address sources of future growth. To their surprise, the most successful in the sample of 60 new firms from Sweden, are coming from the firms which stressing design, instead of technology, in their innovation (Utterback et al., 2006). In the late '90s, Verganti (2009) also started investigating successful innovation practices in Italian design-intensive manufacturers - later on he expanded globally -and the result demonstrated that radical innovation of product meanings, leads to products with long lives, significant, sustainable profit margins, brand value, and company growth.

Verganti (2008) identifies 3 approaches to innovation as shown in Figure I, namely market-pull, technology-push and design-driven approach. Market-pull innovation starts with user analysis of user needs and then searches for technologies that can better satisfy them, or updates product languages to respond to existing trends. With the market pull approach, the market is the main source of innovation, and new product development is a direct consequence of explicit needs expressed by the consumers. The primary assumption of this approach is that user needs are explicit elements that can be identified, captured, and translated into new products that satisfy those needs (lansiti and Khanna, 1995). Technology-push approach looks at the innovation process from completely different perspective. Rather than being driven by the market, innovation stems from the company's research and development activities that, through the identification and development of new technologies, allow it to create new products (Abernathy and Clark, 1985). Design-push approach is complementary to market pull and technology-push. In the design-push approach, innovation stems from a third knowledge source, one that adds knowledge about user need and technological opportunities (Verganti, 2003, 2006). Radical innovation of meanings does not come from user-centered approaches. Design-driven innovations are instead proposals, which however, are not dreams without a foundation. They end up being what people were waiting for, once they see them. They often love them much more than products that companies have developed by scrutinizing users' needs. 
To produce products which are design-driven innovation, companies need researchers who "envision and investigate new product meanings through a broader, in-depth exploration of the evolution of society, culture, and technology acting as interpreters who are able to envision how people could give meaning to things through intense involvement in the design discourse" (Verganti, 2008). Design discourse is a circle or a network of people, such as artists, cultural organizations, media, retail and delivery firms, designers, architects, technology suppliers, and research and educational institutions. These interpreters are engaged in a continuous dialogue about new products, people's needs and values.

However, listening to them is just one part of the strategy. The company itself must do an internal research and some experiments that enable it to eventually create its own vision and proposal that develop a radically new meaning to a product (Verganti, 2008). Companies that produce designdriven innovations are those that highly value their interactions with these interpreters as shown in Figure 2. These companies understand that knowledge about meanings is diffused throughout their external environment that they are immersed in a collective research laboratory where interpreters pursue their own investigations and are engaged in a continuous mutual dialogue.

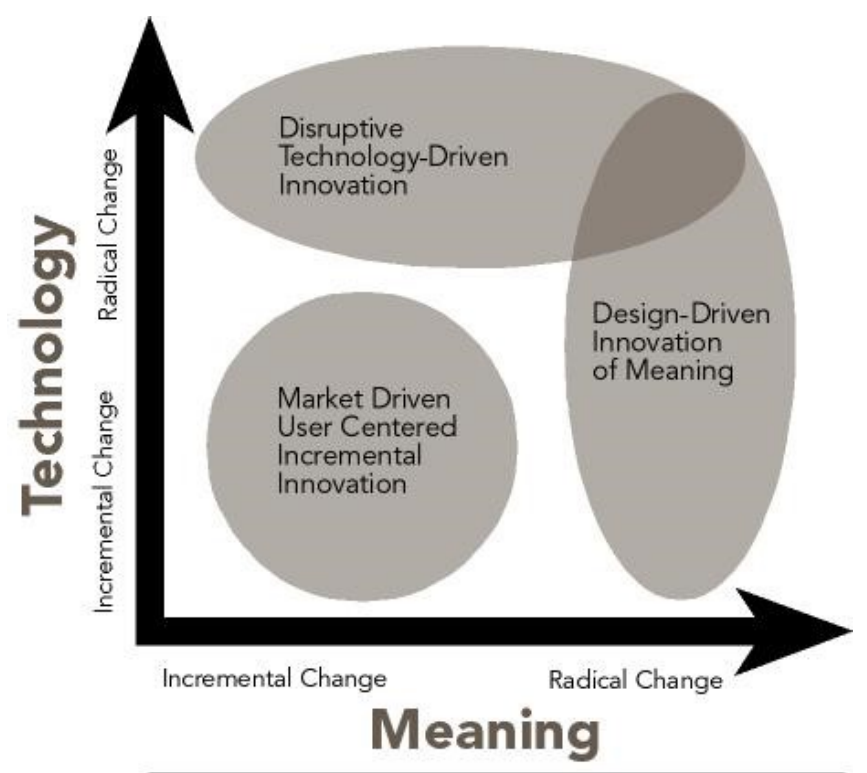

Design Driven Innovation by Roberto Verganti
Verganti (2009) proposes three distinct process stages of design-driven innovation. The first one is listening, which deals with active involvement in a typical design discourse and interaction with various interpreters, by which a company can collect information about possible new product meanings. The capabilities that companies should develop in this stage are how to find, attract and develop a close relationship with key interpreters who are focusing themselves researching the possible trend and developing unique visions about how meanings could evolve in the live context the company wants to investigate. The second action is interpreting, which is the internal process where the knowledge is gained from previous listening stage before it is recombined and integrated with the company's own proprietary insights, technologies, and assets. The outcomes of this process would be a radically new product meaning. The third action is addressing, where a company presents the results of its interpretation about a radically new meaning to the key interpreters whom the company partner with and ask them to use their seductive power to educate the prospective customers about the new product meaning, which is often unexpected, and sometimes confuses people initially.

Figure I. Design-driven Innovation Strategy

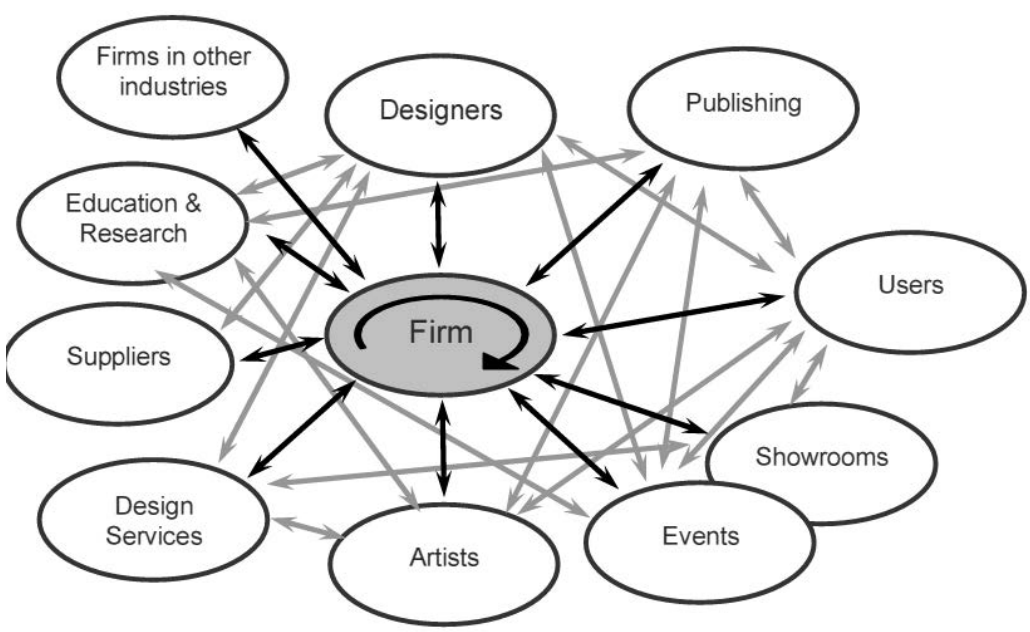

Figure 2. The interpreter and design discourse (Verganti, 2008)

ISSN: 07I 8-2724. (http://www.jotmi.org) 


\section{Creative Industry}

Nowadays, the creative industries have become increasingly important to economic well-being, as suggested by Florida (2002, p. xiii) who states that "human creativity is the ultimate economic resource" and Landry and Bianchini (1995, p. 4) who state that "the industries of the twentyfirst century will depend increasingly on the generation of knowledge through creativity and innovation". What is more it has been proventhat creative industry has survived the economic crisis and has an interesting characteristic whose development trajectory is different from country to country and whose pathways are to be found at the subnational level - in cities and regions in developing countries." (UN 20I0, UN 20I3). In Indonesia, the creative economy waves start to ripple sincethe government began looking for ways to improve the competitiveness of the national products facing the intensifying global market competition. Then, government through the Ministry of Trade in cooperation with the Ministry of Industry and Ministry of Cooperatives and Small and Medium Enterprises (SME) and supported by the Chamber of Commerce established the Indonesia Design Power Team, working from 2006 to 2010, whose aim is to make Indonesian products to be products that can be accepted in the international market and still maintains the Indonesian national identity.

Unfortunately, all of the above-mentioned promising strategic roles of design driven innovation for competing in a global market, research done on these matters are still very limited in developing countries like Indonesia even in developed country like UK as stated in NESTA Report "innovation in the creative industries turns out to be hidden. Many creative businesses still struggle to formalize their innovation processes" (NESTA, 2010). Therefore, research related to the design and innovation in the creative industry should be very appropriate and necessary to be an input to both the players and the decision makers in the related fields. Comparing to the "technology road", "design road" has two advantages, especially for developing countries like Indonesia, i.e. cost and likelihood of success. Firstly, unlike the technology approach, where the investment on both human skills and tools are needed, for the design approach, the main investment is mostly on the things for improving the design skills. Secondly, history has proven that Indonesia has a great potential of creativity. Besides, it is believed that creativity is closely related to design.

\section{Research Design}

This research study is focused on exploring how design driven innovation,from the management perspectives, isimplemented in indonesian creative industry. Therefore, the research problem is formulated as follows how does creative industry in Indonesia carry out a design driven approach in its innovation process which could be subdivided into the following research questions:

RQ I: How does creative industry design a new product meaning for a new costumer?

RQ 2: How does creative industry translate the design with a new meaning into a new product?

RQ 3: How does creative industry deliverthe new products into the markets?

In order to identify the critical variables (Yin, 2003), the appropriate methodology is exploratory case study for the phenomenon is not yet fully understood and no clear boundaries with its context.. This allows researchers to introduce the problem or concept to be studied, and perhaps generate hypotheses to be tested. Exploratory case studies also provide the background information necessary to plan a descriptive or further explanatory study.

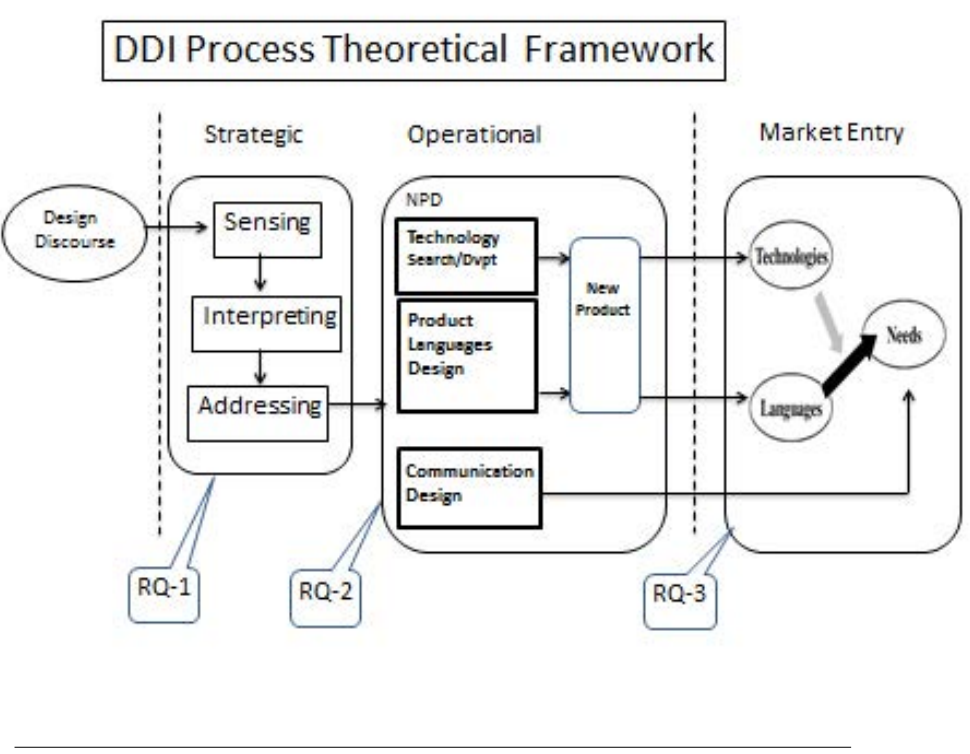

Figure 3. DDI Process Theoretical Framework 


\section{DDI Process Theoretical Framework}

The main objective of this research is to explore and describe how design driven innovation, from management point of view, is implemented in the Indonesian creative industry. Based on the literature review above, DDI process theoretical framework is developed as shown in Figure 3.

The Theoretical Framework consists of two subsystems: Strategic Design Subsystem and Operational Subsystem.

(a). Strategic Design, where its main activities are:

- Sensing the trend in new lifestyles and new technology by involving and discussing intensively in design discourse.

- Interpreting the results of sensing activities by analyzing and selecting the most appropriate idea according to the company's vision and internal assesment.

- $\quad$ Addressing the selected idea as a high level concept with its main elements should include, among others: ProductVision, Design Statements, Future/Anticipated Socio-Cultural Context.

(b). Operational Design, where its main activities are:

- New Product Development (NPD), whose main elements are Technology Searching/Development, Product Language Design, Product Development;

- Communication, which is focused on designing the best strategy to communicate the new value embedded in aproduct to potential costumers.

\section{Case Selection}

Based on the characteristics of industry which performs design-driven innovation (Verganti, 2008), the criteria were developed to choose companies that belong to Indonesian creative industry as follows:

I. Their product or service delivers a new meaning to the existing materials or products.

2. Their product or service is indigenous and has a unique position (brand identity) in the market.

3. Their product has already received some kind of awards or recognitions.

Since so little does prior knowledge about the criteria exist, it is necessary to do interviews with the experts in this field to ensure that the above-mentioned criteria are relevant. These interviews are also necessary because the criteria will be used to identify the companies in Indonesia that have performed design-driven innovation according to Verganti's criteria. In relation with this, two experts from the Faculty of Arts and Design of Bandung Institute of Technology are available to be interviewed and whose short profile is presented in Table I.

\begin{tabular}{|c|c|c|c|c|}
\hline No & $\begin{array}{c}\text { Expert } \\
\text { interviewed }\end{array}$ & Data Source(s) & $\begin{array}{c}\text { Institution/Special- } \\
\text { ization }\end{array}$ & Achievement / Recognitions \\
\hline LI & Lecturer I & Open Interview & $\begin{array}{l}\text { Faculty of Art and } \\
\text { Design ITB /research } \\
\text { group of Design \& } \\
\text { Visual Culture Sci- } \\
\text { ences }\end{array}$ & 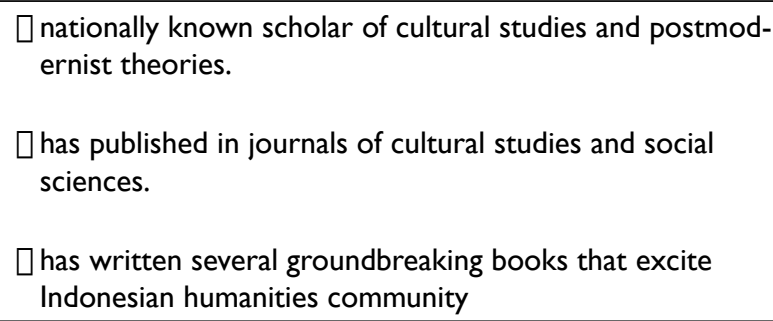 \\
\hline L2 & Lecturer 2 & Open Interview & $\begin{array}{l}\text { Faculty of Art and } \\
\text { Design ITB / re- } \\
\text { search group of Man } \\
\text { \& Industrial Products }\end{array}$ & $\begin{array}{l}\text { Chief Designer Armor Personnel Vehicle, LAPI ITB-Cipu- } \\
\text { tra Group (2004-Now). } \\
\\
\text { Chief Designer National ElectriCar from ITB (2008-now) }\end{array}$ \\
\hline
\end{tabular}

Table I. The Profiles of the InterviewedExperts

ISSN: 07I 8-2724. (http://www.jotmi.org)

Journal of Technology Management \& Innovation (c) Universidad Alberto Hurtado, Facultad de Economía y Negocios. 
In the interviews, the two experts confirmed the above-proposed criteria.They also suggested five design-preneurs, and surprisingly both mentioned the two same design-preneurs. These two same designpreneurs are both chief designer and CEO.Therefore, they know that a design and innovation play an important role in a new product development activity. The face-to-face open interviews were conducted only with the three of them, while the information of the other two was gained from websites. The short profile of thesefive design-preneurs are listed in Table 2.

\section{Data Collection}

A qualitative interview grid to conduct the interviews, as shown in Table 3, was used.The face-to-face interviews were semi-structured and focused so that the selected phenomenon can be studied in detail. The questions were prepared based on the information from the literature review, research objective, research questions and the constructs in theoretical framework. A digital recorder was used wherever possible. Respondents were asked for their permision to use the recorder.

\begin{tabular}{|c|c|c|c|}
\hline No & $\begin{array}{l}\text { Person/ Com- } \\
\text { pany } \\
\text { interviewed }\end{array}$ & Data Source(s) & DDI Signs \\
\hline DI & $\begin{array}{l}\text { Designpreneur } \\
\text { /Design Consul- } \\
\text { tant }\end{array}$ & Open Interview & $\begin{array}{l}\text { a multidisciplinary design consultant with services that range from generating } \\
\text { new brands, to rejuvenatingor extendingof the existing brands } \\
\text { since } 2010 \text {, yearly has published Indonesia Trend Forecasting } \\
\text { For the next } 2 \text { yars focused on fashion trends }\end{array}$ \\
\hline D2 & $\begin{array}{l}\text { Designpreneur } \\
\text { Mooden Radio }\end{array}$ & $\begin{array}{l}\square \text { Open Interview } \\
\square \text { Website }\end{array}$ & $\begin{array}{l}\text { Producing AM/FM radios that: } \\
\text { are made of sustainable ebony wood and crafted by local Indonesian carpen- } \\
\text { ters in areas of high unemployment } \\
\square \text { havean appealing mix of retro and modern styling. }\end{array}$ \\
\hline D3 & $\begin{array}{l}\text { Designpreneur } \\
\text { Mordplay Pic- } \\
\text { torial }\end{array}$ & Open Interview & $\begin{array}{l}\text { addressing visual works (wordplay) poured into media such as t-shirts, } \\
\text { suitcases, and bags. }\end{array}$ \\
\hline D4 & $\begin{array}{l}\text { Designpreneur } \\
\text { / T-Shirt }\end{array}$ & Website & $\begin{array}{l}\text { producing t-shirt souvenirswith a fusion of popular culture and classic elements, } \\
\text { for example: } \\
\text { capturing the localities such as the city's landmarks, cuisine and football club } \\
\text { into its designs } \\
\text { being engaged in a variety of activities that enables the companyto keep in } \\
\text { touch with city's history, such as cultural tourism, community talks and the like } \\
\text { regularly inviting designers to submit their concepts. If chosen, they will be } \\
\text { entitled to royalties. }\end{array}$ \\
\hline D5 & $\begin{array}{l}\text { Designpreneur } \\
\text { /Silver \& Gold } \\
\text { Jewelry }\end{array}$ & Website & $\begin{array}{l}\text { Producing silver and gold jewelry designs that } \\
\text { contain natural story in themlike water, rice, wood, fallen leaves, scattered } \\
\text { twigs, fences, rocks, sea, shells, grass, and shrubs . } \\
\text { give an impression of luxury, sophisticated, elegant, and eclectic. }\end{array}$ \\
\hline
\end{tabular}

Table 2. The profiles of the Selected Creative Industry Designpreneurs 


\section{Data Analysis}

Qualitative data analysis requires aresearcher to move constantly between inductive and deductive thinking as he/she moves through such stages as identifying code categories and their attributes, developing working hypotheses that describe the relationships among the categories, refining the hypotheses and forming higher-level generalizations from the data (Glaser and Strauss, 1967). For this research, this principle is implement by adopting the recommendations of Saldana (2009), in which cycles of coding are used.

\section{CYCLE ZERO}

In Cycle Zero, all of the interviews were transcribed and then coded with the help of NVIVO I0 software. This software then inductively generates the categories and their attributes for each case (within case coding), deductively checksthese emerging categories and their attributes against the data and revises the categories and attributes appropriately. From various coding techniques available, for the first cycle of coding, NVivo Coding Technique (Saldana, 2009) was chosen because it is the most appropriate, simple and direct. From the 7 initial coding of the in-depth interviews, 112 codes were produced.

\section{CYCLE ONE}

The focus of this cycle is first to overview all the 112 codes form all cases (cross-case coding) before reducing theminto 29 codes by eliminating the redundancy among the codes or by merging the codes that are considered to have a similar meaning. Secondly, the29 codes are then regroup and classified into fewer number of codes and more manageable codes, which are 7 codes. These codes are shown in Table 4 and described as follows.

\section{- $\quad$ Trend Forecasting}

Trend forecasting is conceptualized as an activity of gathering information and analyzing it in an attempt to identify a pattern or trend in the information itself. The following quotation is from case DI who provides an example of this category:"My studio has a research groupbecause when I design something. I need to research information whichthe research I do is the one that is related to a kind of trend forecasting where the basic ingredients of the trend forecasting are lifestyle studies and semiotics so that I could read and drive what I should do particularly lifecycles is becoming shorter, maybe 18 months or even only in I year". From cross-case overview, we found out various ways (techniques) to gather the data needed for forecasting atrend, among others: bodystorming, brainstorming, design discourse, culture code, experience, in-depth interview, and lifestyle study.

\begin{tabular}{|c|c|}
\hline Observed Concepts & INTERVIEW GUIDE QUESTIONS \\
\hline LISTENING & $\begin{array}{l}\text { How do you search for ideas containingnew or radical product/services meaning? } \\
\text { What kind of information you are looking for? Where dothe external sources came } \\
\text { from? How do you sense and search for relevant technology? } \\
\text { Do you attend any kind of design expert community, association, or club meeting, phys- } \\
\text { ically and/or virtually? } \\
\text { Do you attend any kind of design expert community, association, or club meeting, regu- } \\
\text { larly? }\end{array}$ \\
\hline INTERPRETING & $\begin{array}{l}\text { How do you compile and systematize all information you obtain from sensing the activ- } \\
\text { itiy/activities above? }\end{array}$ \\
\hline ADDRESSING & $\begin{array}{l}\text { From the compilation of ideas and new trends mentioned above, how do you select } \\
\text { the most promising one? How do you develop new product vision (proposal) from the } \\
\text { selected best idea? }\end{array}$ \\
\hline $\begin{array}{l}\text { TECH SEARCHING AND } \\
\text { DEVELOPMENT }\end{array}$ & $\begin{array}{l}\text { How do you translate a new product vision (proposal) into technology requirements? } \\
\text { How do you search and/or develop technology required to realize the new product } \\
\text { vision (proposal)? }\end{array}$ \\
\hline LANGUAGE DESIGN & $\begin{array}{l}\text { How do you translate the product Vision (proposal), especially related to new product } \\
\text { meaning into product language design? }\end{array}$ \\
\hline COMMUNICATION DESIGN & $\begin{array}{l}\text { How do you translate the product Vision (proposal), especially thenew product mean- } \\
\text { ing into a communication design? }\end{array}$ \\
\hline PRODUCT DEVELOPMENT & $\begin{array}{l}\text { How do you integrate the result of technology searching, development and product's } \\
\text { language designs into a new product? }\end{array}$ \\
\hline
\end{tabular}

Table 3. Interview questionguide

ISSN: 07I 8-2724. (http://www.jotmi.org)

Journal of Technology Management \& Innovation (c) Universidad Alberto Hurtado, Facultad de Economía y Negocios. 
- Design paradigm

Design paradigm is a framework containing the basic assumptions, ways of thinking, concepts, values and methodology that arecommonly accepted by members of a design community. From cross-case overview, we found out various design paradigms or design principles that emerge during an interview, among others: ecofriendly-design emotional design, new craft, new aesthetic, slow design and sustainability design. The following is a quotation from case D2 who provides an example of this category:"First principles,"less wood more works", which means using minimal wood can provide as many jobs as possible. Craft production systems and highly design products provide these opportunities. In one year we just cut down 2 trees for each of our artisans who work in the company. The second principle is 'cut less plant more' which means that we distribute at least $\mathbf{8 0 0 0}$ seeds of tree to the public to be planted every year in their own land, provide guidance and control on the plants that we distribute. So, the good use of wood materials should actually create a new forest ..."

\section{- $\quad$ Product Languages}

Product Language is a symbolic language developed to communicate the meaning of product to humans in a similar way humans develop their language that is needed and used to deliver a meaning between them. The following quotation is from case LI who provides an example of this category: "To design new meaning, first we must study the socio-cultural context of our target users, especially their lifestyles. For example, if we target high-class users, then we should first study their lifestyles (tastes orientation, character, etc), such as: what newspaper they usually read, what kind of movies they usually watch, what kind of musics they usually listens, etc. Then from all these habits, we try to discover what their common product languages, and use it in designing a certain product, for example a watch, so that it will match to their lifestyles."

From cross-case overview, it was found out various ways (techniques) how to gather the data needed for analyzing and developing a product language, among others: media study, metaphor study, semiotic study, and images study.

\section{- Information management}

Information management is a system of managing all necessary data for a certain field or discipline (usually supported by information technology) to support the users to analyze and process them into more meaningful information. The following quotation is from case LI who provides an example of this category:"Therefore, one important and strategic thing for product design management is actually information management, i.e.: how to collect and manage images (image database) which will be used in 2 ways: as a source of inspirations and as a reference to test our ideas."
From cross-case overview, it was found out various kinds of data or study results considered could be pooled into a database and managed by an information management system, i.e.: trend analysis database (as a result of lifestyle study, bodystorming, imperience, etc.), image database (as result of an image study, metaphor study, media study, etc.), and technology database (as a result of technology study).

\section{- $\quad$ Storytelling}

Storytelling is a method of illustrating a new meaning that is intended to be delivered through alanguage assigned to aproduct, through a narrative way, based on the premise that people remember information better when it is told as a story thanwhen it is presented as a list of facts because stories are more relatable and evokean emotional reaction (empathy, sympathy, outrage or laughter) to the audience. The following quotations arefrom case L2 and D2 who provide an example of this category: (L2).."Yes...we have an origin... Every design has an origin ... Every designer will show where his/her idea comes from... This roof originates from the Minangkabau tribal house etcetera ..., so we make a story ... about this design..."

(D2)"...The story of this life and work is an integrated part of this village. That is, what we want to offer. People not only buy our wooden-radio products, but by buying our product they also support the sustainability concept ofour village."

\section{- $\quad$ Sustainable competitive advantage}

Sustainable competitive advantages are company assets, attributes, or abilities that are difficult to duplicate; theyprovide a superior or favorable long term position over competitors. The following quotation is from case LI who provides an example of this category: "Product with a strong design and with a unique meaning or a clear message of its product language will be sustainable in acompetition because it touches and staysin the unconsciousmind of the users."

\section{- Design-preneur}

Design-preneur is a person who is the chief designer and at the same time also the CEO of acompany. Therefore, he/she knows well that both adesign and innovation play their important roles in the R\&D processes. The following quotation is from case D2 who provides an example of this category: "Nevertheless, there is a quite significant number of designers who choose to pioneer their own businesses. They are not just designing but also producing." 


\begin{tabular}{|c|c|c|}
\hline $\begin{array}{c}\text { CycleZero } \\
\text { (Initial Coding) }\end{array}$ & $\begin{array}{c}\text { Cycle One } \\
\text { (Focused Coding) }\end{array}$ & $\begin{array}{c}\text { CycleTwo } \\
\text { (Thematic Coding) }\end{array}$ \\
\hline Trend forecasting & \multirow{9}{*}{ Trend forecasting } & \multirow{9}{*}{ SENSING } \\
\hline Bodystorming & & \\
\hline Brainstorming & & \\
\hline design discourse & & \\
\hline culture code & & \\
\hline Imperience & & \\
\hline in-depth interview & & \\
\hline lifestyle study & & \\
\hline surface culture & & \\
\hline ecofriendly-design & \multirow{7}{*}{ Design paradigm } & \multirow{7}{*}{ SENSEMAKING } \\
\hline emotional design & & \\
\hline new cratt & & \\
\hline new esthetique & & \\
\hline slow design & & \\
\hline Sustainability & & \\
\hline Wisdom & & \\
\hline Product Language & \multirow{5}{*}{ Product Language } & \multirow{7}{*}{ SEIZING } \\
\hline media study & & \\
\hline metaphor study & & \\
\hline semiotic study & & \\
\hline images study & & \\
\hline Image database & \multirow{2}{*}{ Information management } & \\
\hline Information management & & \\
\hline Marketing Strategy & & \multirow{2}{*}{ SPECIFYING } \\
\hline New Product Development & & \\
\hline Storytelling & Storytelling & STORYTELLING \\
\hline sustainable competitive advantage & sustainable competitive advantage & SUSTAINABLE COMPETITIVE ADVANTAGE \\
\hline Design-preneur & \multirow{3}{*}{ Design-preneur } & \multirow{3}{*}{ Design-preneur } \\
\hline Personal Story & & \\
\hline Passion & & \\
\hline
\end{tabular}

Table 4. Categorization and Abstraction 


\section{CYCLETWO}

Cycle Two focuses on the inductive identification of the relationships between the identified categories in Cycle One. Cycle Two isa bit more challenging because it requires analytical skills such as synthesizing, abstracting, conceptualizing, and theory building (Saldana, 2009). These hypothesized relationships are then deductively checked against the interview database and compared to relevant literature in the field. There are two outcomes of this stage. The first is a conceptual framework, as shown in Figure 4, that addresses the important constructs of design-driven innovation process, which were identified in this study and in their hypothesized relationships. The second outcome is a comparison between this conceptual framework with the selected studies in the literature review which is represented inthe theoretical framework as seen in Figure 3.

\section{DDI Process Conceptual Framework}

Figure 4 represents the model of ongoing, working DDI Process Conceptual Framework which is developed from the interview database in this study. The conceptual framework displays the five categories: SENSING, SENSEMAKING, SPECIFYING, SETTING UP and STORYTELLING. They were identified in the process of data analysis and in the hypothesized relationships between the categories. It is important to point out that the lines that connect the categories in the framework do not imply causality or temporal precedence; they should only be interpreted as implying a hypothesized relationship between the categories.

\section{SENSING}

Sensing in a design context is the activity of scanning lifestyles in a certain socio-cultural context, and it tries to detect as early as possible any potential changes (weak signals) that emerge before collecting all of the information about them. The interview data reveal that the industry applies various methods in sensing the lifestyle trends, among others: by bodystorming, brainstorming, design discourse, culture coding, imperience, in-depth personal interview and lifestyle study. The output of all these methods could be collected and managed as a trend forecasting data.

\section{SENSEMAKING}

Sensemaking is the activity of interpreting the trend forecasting data which come from the sensing activity before assigning them with personal meanings. Sensemaking process in this case is strongly influenced and filtered by a system of actions and beliefs (Weick, 1995; Choo, 1996) or by

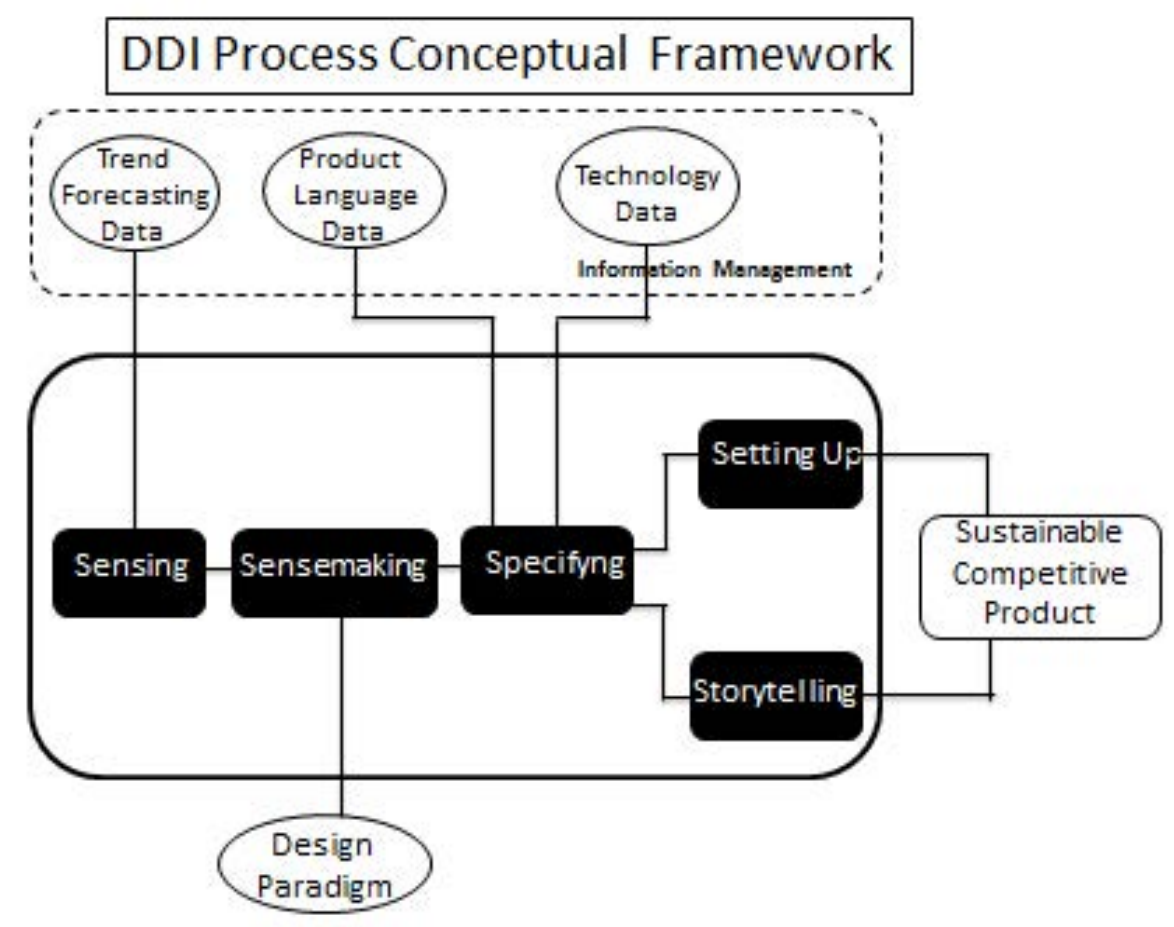

Figure 4. DDI Process Conceptual Framework

ISSN: 07 I8-2724. (http://www.jotmi.org)

Journal of Technology Management \& Innovation (c) Universidad Alberto Hurtado, Facultad de Economía y Negocios. 
the design paradigm of the designer which could be among others: ecofriendly-design, emotional design, new craft, new aesthetic, slow design and sustainability as included in the interview data. Even though the designer already has a certain paradigm filter to discern the meaning from data, at first cycle usually there are several alternative insights that are produced. After the cycles of sensemaking and contemplating, the amount of insights should be reduced into one or a limited number to be processed in next stage.

\section{SPECIFYING}

In the specifying stage, a designer starts to translate the final insights or meanings into the design concepts by selecting and specifying the appropriate product languages and suitable technologies from the relevant databases. This stage is more or less following Krippendorff's (2006) circular process of "sense", "meaning" and "action", which means that after attributing meaning to something in the activity of sensing, then that thing is realized in into an action. Since the focus of adesign-driven innovation approach is on the innovation of a new or radical meaning rather than on technology, the next stage is finalizing a design concept. In this stage, there are two activities such as setting up and story telling as follows.

\section{a. SETTING UP}

In the setting up activity, the design concepts from previous stage will be further elaborated and detailed into a complete specification ready to use as technical instructions. These technical instructions will be used to develop a new prototype and a production or manufacturing planning of a final product.

\section{b. STORYTELLING}

Storytelling, whoseconcept has already been described in the previous paragraph, has a strategic role in preparing, conditioning and educating the prospective customers for a product, having a new or radical meaning,which will be delivered to them so that the meaning can reside in their mind even before they see the product.

\section{Discussion}

This research has identified three differences based on what is revealed in the interview data (represented by Conceptual Framework) and what is explained in the literature review (represented by Theoretical Framework) as shown in Table 5 (next page).

The first finding shows that none of the interviewed designpreneurs mentions about both interpreter and design-discourse, which are not considered or not yet recognised as strategic components as explained by Verganti (2009) in the literature review section. In fact, the role of the interpreter is performed by the design-preneur him/herself, as explain by one of the respondents:

(D2) "In designing, I cannot start the process with a completed and detailed concept. This will ensure the loss of my mood and energy. Sometimes the design process is triggered with only a tiny clue from my surroundings. For me, designing is like a trip without a map. I make an effort to enjoy the process and savor the meaning of the trip.

Like any voyage, sometimes the objective is very clear but the journey is blurry or sometimes both are blurry. But in the end of the journey, I know that there will be something with a deeper meaning which awaits me.

I never start my design according to the market research or demand. I design by absorbing events, global or local events and even mundane daily life things that happen around me. Consequently, I start to think what will be good and better for these people."

Second finding shows that the source of idea for developing a new meaning comes from various data gathering techniques such as: bodystorming, brainstorming, design discourse, culture code, imperience, in-depth interview and lifestyle study. Design discourse is considered only as one of various methods available, while according to literatur review, the source of idea for new meaning creation is gained mostly through interacting with interpreters in a design discourse (Verganti, 2009). A qoute from a respondent even shows that none of them mentions about both interpreter and design discourse: 


\begin{tabular}{|c|c|c|}
\hline Theoretical Framework (TF) & Conceptual Framework (CF) & Differences with TF \\
\hline $\begin{array}{l}\text { Listening } \\
\text { the action of gaining access to knowledge about } \\
\text { possible new product meanings by interacting } \\
\text { with interpreters(forward-looking researchers } \\
\text { who are developing unique visions about how } \\
\text { meanings could evolve in the life context to be } \\
\text { investigated) through a design discourse. }\end{array}$ & $\begin{array}{l}\text { Sensing } \\
\text { The activity of scanning lifestyles in a cer- } \\
\text { tain socio-cultural context and of trying } \\
\text { to detect as early as possible any potential } \\
\text { changes (weak signals) that emerge before } \\
\text { collecting all of the information about } \\
\text { them. }\end{array}$ & $\begin{array}{l}\text { In CF, Design-discourse is not consid- } \\
\text { ered or not yet recognised as a stra- } \\
\text { tegic componentas in TF.Therefore,in- } \\
\text { terpreters are not known. In fact, the } \\
\text { interpreting role is performed by the } \\
\text { design-preneur him/ herself. }\end{array}$ \\
\hline \multirow[t]{2}{*}{$\begin{array}{l}\text { Interpreting } \\
\text { the internal process through which the firm } \\
\text { assesses the knowledge it gains by interacting } \\
\text { with interpreters and then recombines and } \\
\text { integrates this knowledge with its own insights, } \\
\text { technologies, and assets. Its outcome is the } \\
\text { development of a breakthrough meaning for a } \\
\text { product family. }\end{array}$} & $\begin{array}{l}\text { Sensemaking } \\
\text { Sensemaking is the activity of interpreting } \\
\text { the trend forecasting data which comes } \\
\text { from the SENSING activity, before assign- } \\
\text { ing them withpersonal meanings. Sensem- } \\
\text { aking process in this case is strongly influ- } \\
\text { enced and filtered by the design paradigm } \\
\text { of the designer. }\end{array}$ & $\begin{array}{l}\text { In CF, the source of information comes } \\
\text { from the trend forecasting data, while } \\
\text { in TF information is gained mostly } \\
\text { through interacting with interpreters. }\end{array}$ \\
\hline & $\begin{array}{l}\text { Specifying } \\
\text { The designer starts to translate the final } \\
\text { insights or meanings into the design con- } \\
\text { cepts by selecting and specifying the ap- } \\
\text { propriate product languages and suitable } \\
\text { technologies from the relevant databases. }\end{array}$ & $\begin{array}{l}\text { Only in CF, the interpreting stage is } \\
\text { sub-dividedinto 2: Sensemaking and } \\
\text { Specifying. }\end{array}$ \\
\hline $\begin{array}{l}\text { New Product Development (NPD)whose- } \\
\text { main elements are Technology Searching/Devel- } \\
\text { opment, Product Language Design andProduct } \\
\text { Development }\end{array}$ & $\begin{array}{l}\text { Setting } U_{P} \\
\text { The design concepts from previous stage } \\
\text { will be further elaborated and detailed } \\
\text { into a complete specification ready to use } \\
\text { as technical instructions to develop anew } \\
\text { prototypye and production or manufactur- } \\
\text { ingplan of a final product. }\end{array}$ & Basically, there are no differences. \\
\hline Addressing & \multirow{3}{*}{$\begin{array}{l}\text { Storytelling } \\
\text { It sillustrates a new meaning that is in- } \\
\text { tended to be delivered through anarrative } \\
\text { way, based on the premise that people } \\
\text { remember information better.Stories are } \\
\text { more relatable and evokean emotional } \\
\text { reaction (empathy, sympathy, outrage or } \\
\text { laughter) ofthe audience. }\end{array}$} & \multirow{3}{*}{$\begin{array}{l}\text { In CF, since there is no special inter- } \\
\text { preters involved, seductive power is } \\
\text { not available. Therefore, astoryline is } \\
\text { developed as a way to touch the emo- } \\
\text { tion of prospective costumers so that } \\
\text { the new radical meaning can reside in } \\
\text { their minds. }\end{array}$} \\
\hline $\begin{array}{l}\text { Radical innovations of meanings, which areun- } \\
\text { expected and sometimes initially confuse peo- } \\
\text { ple. To prepare the ground for groundbreaking } \\
\text { proposals, firms leverage the seductive power of } \\
\text { interpreters. }\end{array}$ & & \\
\hline $\begin{array}{l}\text { Communication } \\
\text { focused on designing the best strategy to com- } \\
\text { municate the new value embedded in the prod- } \\
\text { uct to the potential costumers. }\end{array}$ & & \\
\hline
\end{tabular}

Table 5. Comparison betweenthe Theoretical Framework andthe Conceptual Framework 
(DI) "To design new meaning, we first study the socio-cultural context of our target users, especially their lifestyles. For example, if we target high-class users, then we should first study their lifestyles (tastes orientation, character, etc.), such as: what newspaper they usually read, what kind of movies their usually watch, what kind of musics they usually listens, etc. Then from all these habits, we try to discover what their common product (visual) language isand use it in designing a certain product, for example: a watch,so that it will match to their lifestyles".

The third finding shows that since there are no special interpreters involved, seductive power is not available. Therefore, astoryline (already described in previous paragraph) is developed as a way to evoke the emotion of prospective costumers so that the new radical meaning can reside in their minds.

\section{Implications for theory and practice}

From the theoretical point of view, the exploratory case research of several local design-preneur has led small scale creative industries to reveal that it is not mandatory to actively immerse in a design discourse and engage with key interpreters (Verganti, 2009) in order to be successful in creating and delivering a new product meaning into the market. There are several other ways,as mentioned in the interviews, besides design discourse in sensing the change or trend in a particular socio-cultural context as a necessary input for the company todevelop a new meaning. Consequently, since they do not have any interaction or engagement with key interpreter(s), they themselves who design and develop the new meaning along with its storyline to prepare and supports the delivery of the new meaning into the minds of the prospected costumers even before the product reaches them.

From the practical point of view, the results of this research provide interesting guidelines for any designer who has a strong passion to become a successful design-preneur. From the managerial point of view, this study suggests that firms can develop a new product meaning successfully by following 5 steps below. Firstly, to create a new meaning, sensing the trend forecasting data should be done. The data should then be collected by various methods to obtain various possible new meanings. Secondly, in the sensemaking stage, select and define one of possible new meanings which is considered to be the best in anticipating a new trend. Thirdly, translate this defined new meaning into a new product by selecting the most suitable product language, supported by selected appropriate technology, to express the defined new meaning. Fourthly, set up the the new product development program by using the selected product language that is considered suitable to express the defined new mean- ing. Fifthly, to deliver the new product with its defined new meaning, a storyline should carefully be designed along with the attached product language to amplify and to relate the massage of the defined new meaning into the mind of the potential costumers.

To execute these 5 steps effectively, two important supports are needed. They are as follows: (I) the availability of Stateof-the-art databases of two data groups, i.e. : database of trend study as the main input for the sensing activity and database of both product languages and alternative technologies as the main tools for specifying the sensing activity, and (2) a certain design paradigm, which is passionately intended to be expressed by a designer, which will guide the process of sensemaking and will eventually create a meaning which characterizing the design paradigm itself.

\section{Conclusions}

This exploratory case study research has been able to answer the research problem on how the creative industry in Indonesia carries out a design driven approach in its innovation process. To design new product meaning for new costumers, the company should sense the trend forecasting data which are collected with various methods by which various possible new meanings are produced. Then, the designer with his/her design paradigm helps the company do the sensemaking process in which the one of the possible new meanings is considered to be the best in anticipating a new trend is selected and defined. To translate the defined new meaning into a new product, the most suitable product language to express the defined new meaning -supported by selected appropriate technologies - is selected. The result will be used as specification to develop the new product. To deliver the new product with its defined new meaning into the markets, a storyline is carefully designed along with its product language to amplify and to relate the massage of the defined new meaning to the mind of the potential costumers.

The contribution of this research is that it has revealed that to deliver a new meaning succesfully to the market, at least for the design-preneur-led creative industry, there are ways other than the ones suggested by Verganti (2009), i.e., to actively immerse in a design discourse and to actively engage with key interpreters. Since this is an exploratory study, one of its obvious limitation is the small number of cases that is examined. Therefore, future research should examine the conceptual model in a larger sample of data and expand the research on larger scale, where the role of entrepreneurs is separated from the role of chief-designers. Secondly, since the current conceptual framework is still in its basic phase, further research should also be done to develop a more elaborated and practical model that is ready to be adopted into the innovation strategy of any interested industry. 


\section{References}

ABERNATHY, W., Clark, K.B. (1985). Mapping the winds of creative destruction. Research Policy, I4(I), 3-22. doi: 10.1016/0048-7333(85)90020-4

BEVERLAND, M., Farrelly, F. (2007). What does it mean to be design-led? Design Management Review, 18(4), 10-17. doi: I0.1 I I I/j.1948-7|69.2007.tb00089.x

BUCOLO, S., Matthews, J.H. (20I0). Using a design led disruptive innovation approach to develop new services: Practising innovation in times of discontinuity. In: Kobe, C., Goller, I. (Eds.), Proceedings of the II th International CINet Conference: Practicing Innovation in the Times of Discontinuity, CINet, Zurich, Switzerland, I76-I87.

CHOO, C.W.(1996). The knowing organization: how organizations use information to construct

meaning, create knowledge and make decision. International Journal of Information Management, I6(5), 23-40. doi: 10.1016/0268-40I2(96)00020-5

DOSI, G. (1982). Technological paradigms and technological trajectories:A suggested

interpretation of the determinants and directions of technical change. Research Policy, II (3), I47-I62. doi: 10.1016/00487333(82)90016-6

DC-UK (2008), Design Council Briefing, The Impact of Design on Business, October 2008,

London.

DOTI (2007), Department of Trade of Indonesia, Study of Creative Industry Indonesia 2007, Jakarta.

DOTI (2008), Department of Trade of Indonesia, Plan Economic Development Creative

Indonesia 2009-20I5, Jakarta.

EISENDHARDT, K.M. (1989). Building theories from case study research. Academy of Management Review, I4(4), 53255I. doi: I0.5465/AMR. 1989.4308385

FLORIDA, R. (2002). The Rise of the Creative Class and How It's Transforming Work, Leisure, Community and Everyday Life. Basic Books, New York.

GLASER, B.G.,Strauss,A.L. (1967).The Discovery of Grounded Theory: Strategies for

Qualitative Research. Aldine Publishing Company, Chicago. doi: 10.1093/sf/46.4.555
HENDERSON, R.M., Clark, K.B. (1990). Architectural innovation: the reconfiguration of existing product technologies and the failure of established firms. Administrative Science Quarterly, 35(I), 9-30.

IANSITI, M., Khanna, T. (1995). Technological evolution, system architecture and the

obsolescence of firm capabilities. Industrial and Corporate Change. 4(I), 333-36I.doi: 10.1093/icc/4.2.333

KARTONO, S.S. (2010). Retrieved from wawancara-bersama-bapak-singgih-susilo-kartono/

KRIPPENDORFF, K. (2006).The Semantic Turn:A New Foundation for Design. Taylor and Francis, London.

LANDRY, C., Bianchini, F. (1995). The Creative City. Demos Publication, London.

LANKS, B. (2008). Craft on the Dial. Retrieved from http:// www.metropolismag.com/dukwv2008/craft-on-the-dial.

LARASATI, D., Sudarmadji, B.W. (2008). Creating sustainable business through creativity and good product design: The success story of Mahanagari, ARTE-POLIS 2 International Conference and Design Charrette, Bandung, Indonesia.

NESTA (2008). Hidden Innovation in the Creative Industry. Research Report, NESTA London.

NUSSBAUM, B. (2009). Design thinking battle--managers embrace design thinking: Designers

reject it, Bloomberg BusinessWeek, July.

PRAHALAD, C.K., Santos, J., Pilat, D. (2009). New nature of innovation, Report to OECD, FORA OECD, Copenhagen, September.

SALDANA, J. (2009).The Coding Manual for Qualitative Researchers. Sage, London.

SCHONHARDT, S. (20I I). Company tuned to sustaining resources. Retrieved from

http://www.dispatch.com/content/stories/business/20l I/08/28/company-tuned-to-sustaining-resources. html.

SIGOLOTTO, D. (20I0), Design driven innovation: Innovation strategies adopted in the furniture industry, Unpublished Master Thesis, Politecnico Di Milano, Facoltà Di Ingegneria, Milan, Italy.

UN (20I0). Creative Economy: A Feasible Option. Creative Economy Report.

ISSN: 07 I8-2724. (http://www.jotmi.org) 
UN (20/3). Widening Local Development Pathways. Creative Economy Report.

UTTERBACK, J.M.,Vedin, B.A., Alvarez, E., Ekman, S., Sanderson, S., Tether, B.,Verganti, R. (2006). Design Inspired Innovation. World Scientific Publishing, New York.

VALTONEN,A. (2007). Redefining industrial design: Changes in the design practice in Finland.

Unpublished Doctoral Dissertation, University of Art and Design, Helsinki.

VERGANTI, R. (2003). Design as brokering of languages:The role of designers in the innovation strategy of Italian firms. Design Management Journal, I4(3), 34-42. doi:

I0.IIII/j.1948-7I69.2003.tb00050.x

VERGANTI, R. (2006). Innovating through design. Harvard Business Review, 84(I2), I I4-I 22.

VERGANTI, R. (2008). Design, meanings, and radical innovation:A metamodel and a research

genda. Journal of Product Innovation Management, 25(5), 436-456. doi: I0.1 I I /j. 1540-5885.2008.003 I3.x

VERGANTI, R. (2009). Design Driven Innovation. Harvard Business School Press, Boston.

WEICK, K.E. (1995 ). Sensemaking in Organizations.Sage, New York.

WIKU, (2014). A fusion of history and popular culture. Retrieved from http://www.scoutnetworkblog. $\mathrm{com} / 2012 / 03 / 10500 / a-f u s i o n-o f-h i s t o r y-a n d-p o p u l a r-$ 'culture/

YANUARDI, R. (20I2, April 27). Jewelry designs inspired by nature. jakartapost.com. Retrieved From http://www.thejakartapost.com/news/2012/04/27/jewelry-designs-inspirednature.html

YIN, R.K. (2003). Case Study Research: Design and Methods. 3rd Ed., Sage, New York. 